\section{Cureus}

Received 06/18/2018

Review began 07/16/2018

Review ended 07/19/2018

Published 07/20/2018

(c) Copyright 2018

Shahbaz et al. This is an open access article distributed under the terms of the Creative Commons Attribution License CC-BY 3.0., which permits unrestricted use, distribution, and reproduction in any medium, provided the original author and source are credited.

\title{
Follicular Variant of Papillary Thyroid Carcinoma Presented as Autonomous Functioning Thyroid Nodule: A Case Report and Review of Literature
}

Amir Shahbaz ${ }^{1}$, Mina Fransawy Alkomos ${ }^{2}$, Rupak Mahendhar ${ }^{1}$, Usman Nabi ${ }^{3}$, Maria Riaz ${ }^{1}$, Issac Sachmechi ${ }^{1}$

1. Internal Medicine, Icahn School of Medicine at Mount Sinai/Queens Hospital Center, New York, USA 2. Research, California Institute of Behavioral Neurosciences \& Psychology, Sacramento, USA 3. Diagnostic Radiology, Hamad General Hospital, Doha, QAT

$\square$ Corresponding author: Amir Shahbaz,amirshahbaz89@gmail.com Disclosures can be found in Additional Information at the end of the article

\section{Abstract}

Follicular variant of papillary thyroid carcinoma (FVPTC) presented as an autonomous functioning thyroid nodule is a rare finding. We reported a case of 70-year-old male presented with complaints of palpitation and heat intolerance. On palpation, we found a thyroid nodule of $4 \mathrm{~cm}$ in the left lobe. Thyroid function tests revealed hyperthyroidism, and radioactive iodine uptake scan (RAIU) showed increased uptake in the left lobe consistent with a hot nodule. The probability of the benign nature of hyperfunctioning thyroid nodule discussed but patient requested further workup to rule out any remote possibility of thyroid cancer. We performed a fine needle aspiration (FNA), and the cytological examination suggested the possibility of thyroid carcinoma. The patient underwent total thyroidectomy, and histological examination revealed follicular architecture with nuclear features of papillary carcinoma in $1 \mathrm{~cm}$ area of the thyroid nodule. In the review of the literature, we identified the following seven cases of FVPTC arising within a hyperfunctioning thyroid nodule.

Categories: Endocrinology/Diabetes/Metabolism, Oncology

Keywords: thyroid nodule, thyroid carcinoma, hyperthyroidism

\section{Introduction}

A thyroid nodule is a common problem in clinical practice. Thyroid nodule $>1 \mathrm{~cm}$ in any diameter required a serum thyroid stimulating hormone (TSH) level. If the serum TSH is subnormal, a radioiodine uptake thyroid scan should be obtained to document the functional status of the thyroid nodule. Hyperfunctioning nodules rarely harbor malignancy, and no cytological evaluation is necessary [1]. However, the risk of malignancy may be underestimated in the hot nodule. A recent literature review revealed an estimated 3.1\% prevalence [2]. We present a case of a follicular variant of papillary thyroid carcinoma (FVPTC) arising within a hyperfunctioning thyroid nodule.

\section{Case Presentation}

A 70-year-old male, known case of diabetes mellitus, hypertension and coronary artery disease, presented with complaints of increased appetite, weight loss, palpitations and heat intolerance. Physical examination revealed $4 \mathrm{~cm}$ thyroid nodule in the left lobe on palpation. His blood

How to cite this article

Shahbaz A, Fransawy Alkomos M, Mahendhar R, et al. (July 20, 2018) Follicular Variant of Papillary Thyroid Carcinoma Presented as Autonomous Functioning Thyroid Nodule: A Case Report and Review of Literature. Cureus 10(7): e3014. DOI 10.7759/cureus.3014 
pressure was $130 / 85 \mathrm{mmHg}$, and resting pulse was $102 / \mathrm{min}$ with sinus rhythm. His TSH suppressed $0.29 \mathrm{uIU} / \mathrm{mL}$ (Reference range: $0.40-4.00 \mathrm{uIU} / \mathrm{mL}$ ) while free thyroxine (FT4) 2.1 $\mathrm{ng} / \mathrm{dL}(0.8-1.9 \mathrm{ng} / \mathrm{dL})$ and free triiodothyronine (FT3) $4.2 \mathrm{pg} / \mathrm{mL}(1.5-4.1 \mathrm{pg} / \mathrm{mL})$ elevated. In Figure 1, the radioiodine uptake scan showed the abnormal focus of hot uptake in the left lobe, suggestive of a hyperfunctioning toxic thyroid nodule.

Increased Uptake

\section{Anterior with marker}

\section{FIGURE 1: Radioiodine uptake scan.}

The thyroid scan shows a hot nodule in the left lobe and suppression in the remaining thyroid tissue.

The patient had classic signs and symptoms of hyperthyroidism. The possibility of the benign nature of hyperfunctioning thyroid nodule discussed, but the patient requested further workup to rule out any remote possibility of thyroid cancer. A fine needle aspiration (FNA) performed, and the cytology report was suggestive of thyroid carcinoma. The patient then underwent total thyroidectomy. The pathology report confirmed the fine needle aspiration cytology (FNAC) finding and revealed a solitary tumor measuring $3.5 \mathrm{~cm}$ in diameter. The architecture was predominantly follicular, and papillary cytological features were best seen in an area of $1 \mathrm{~cm}$ consistent with a follicular variant of papillary thyroid carcinoma. No other cancerous tissue found in the remaining thyroid gland. Due to the small size of the tumor no ablative radioiodine therapy performed. Post surgery, the patient received levothyroxine to prevent hypothyroidism and to stop TSH stimulation. Serum TSH and serum thyroglobulin were checked regularly. On follow-up visit, radioactive iodine whole-body scan did not reveal any distant metastasis. This case is a rare example of FVPTC arising within a toxic nodule.

\section{Discussion}

The term hot nodule of the thyroid is described as an area of greater radioiodine uptake 


\section{Cureus}

compared to the surrounding thyroid tissue. The presence of a hot nodule is usually believed to exclude the diagnosis of thyroid cancer [3]. The autonomous functioning thyroid nodule presented as a thyroid cancer requires careful evaluation and consideration. The exact incidence is difficult to quantify; one reason for this is the variability in how hot nodules defined. When malignancy is present it may coexist with hyperfunctioning tissue in the same gland but at different sites [4]. Pazaitou-Panayiotou et al. explored the relationship between thyroid cancer and hyperthyroidism. In seven out of 17 patients with hyperthyroidism associated solitary autonomous adenomas, the tumor located outside the hot nodule [5]. The risk of malignancy in hot nodule increases with family history, large size, rapid growth, irregular outline and lack of mobility within the surrounding tissue [3].

In our case, the patient presented with hyperthyroidism, and localized uptake of ${ }^{131}$ I was consistent with a hot nodule. Fine needle aspiration has a higher false negative rate as the size of the nodule increases. As such, the American Thyroid Association recommends patients with nodules greater than $4 \mathrm{~cm}$ who have indeterminate cytology should undergo total thyroidectomy as the first line of treatment [6]. Follicular variant of papillary thyroid carcinoma is found in $9-22.5 \%$ of patients with papillary thyroid carcinoma. It characterizes as follicular architecture with nuclear features of papillary carcinoma. The nuclear features are subtle; histological interpretation is prone to intra-observer variation and, as such, mistaken for follicular adenoma [7]. In the review of the literature, we found the following cases of the follicular variant of thyroid carcinoma arising within a hot nodule (Table 1).

\begin{tabular}{|c|c|c|c|c|c|c|}
\hline Author & $\begin{array}{l}\text { Reported } \\
\text { year }\end{array}$ & $\begin{array}{l}\text { Patient } \\
\text { age/sex }\end{array}$ & Presentation & $\begin{array}{l}\text { Nodule } \\
\text { detected }\end{array}$ & Treatment & Outcome \\
\hline $\begin{array}{l}\text { Azevedo } \\
\text { \& Casulari [7] }\end{array}$ & 2010 & 47/F & $\begin{array}{l}\text { Weight loss, } \\
\text { nervousness, tremors, } \\
\text { fatigue and insomnia }\end{array}$ & $\begin{array}{l}\text { US neck } \\
+ \text { RAIU + } \\
\text { FNAC }\end{array}$ & $\begin{array}{l}\text { Total } \\
\text { thyroidectomy } \\
+ \text { Radioiodine } \\
\text { Ablation }\end{array}$ & $\begin{array}{l}\text { Was well on follow visit } \\
\text { with no recurrence. }\end{array}$ \\
\hline $\begin{array}{l}\text { Bommireddipalli } \\
\text { et al. [8] }\end{array}$ & 2010 & 63/M & $\begin{array}{l}\text { Five months history of } \\
\text { the progressively } \\
\text { enlarging neck mass, } \\
\text { weight loss, and } \\
\text { fatigue }\end{array}$ & $\begin{array}{l}\text { US Neck } \\
\text { +RAIU+ } \\
\text { FNAC }\end{array}$ & $\begin{array}{l}\text { Total } \\
\text { thyroidectomy } \\
+ \text { Radioiodine } \\
\text { Ablation }\end{array}$ & $\begin{array}{l}\text { One year follow-up } \\
\text { PET/CT scan revealed a } \\
\text { metabolically active pre- } \\
\text { tracheal lymph node, } \\
\text { which on biopsy was } \\
\text { confirmed to be stage III } \\
\text { FVPTC. }\end{array}$ \\
\hline $\begin{array}{l}\text { Ruggeri et al. } \\
\text { [9] }\end{array}$ & 2013 & $15 / F$ & $\begin{array}{l}\text { Symptoms of } \\
\text { hyperthyroidism+ had } \\
\text { a positive family } \\
\text { history of thyroid } \\
\text { cancer }\end{array}$ & $\begin{array}{l}\text { US neck } \\
+ \text { RAIU + } \\
\text { FNAC }\end{array}$ & $\begin{array}{l}\text { Total } \\
\text { thyroidectomy } \\
\text { + Radioiodine } \\
\text { Ablation }\end{array}$ & Not mentioned \\
\hline $\begin{array}{l}\text { Gabalec et al. } \\
\text { [10] }\end{array}$ & 2014 & $15 / F$ & $\begin{array}{l}\text { Hyperfunctioning } \\
\text { thyroid nodule }\end{array}$ & $\begin{array}{l}\text { RAIU+ } \\
\text { FNAC }\end{array}$ & $\begin{array}{l}\text { Total } \\
\text { thyroidectomy+ } \\
\text { Radioiodine } \\
\text { Ablation }\end{array}$ & Disease-free on follow-up \\
\hline $\begin{array}{l}\text { Kuan \& Tan } \\
\text { [11] }\end{array}$ & 2014 & $60 / \mathrm{F}$ & $\begin{array}{l}\text { Enlarged thyroid } \\
\text { mass, dysphagia, } \\
\text { hoarseness, heat } \\
\text { intolerance, }\end{array}$ & + RAIU + & $\begin{array}{l}\text { Total } \\
\text { thyroidectomy } \\
\text { + Radioiodine }\end{array}$ & Not mentioned \\
\hline
\end{tabular}




\section{Cureus}

\begin{tabular}{|c|c|c|c|c|c|c|}
\hline & & & $\begin{array}{l}\text { palpitation and weight } \\
\text { loss }\end{array}$ & FNAC & Ablation & \\
\hline Rees et al. [4] & 2015 & $16 / F$ & $\begin{array}{l}\text { Thyroid mass, weight } \\
\text { loss, tremors, frequent } \\
\text { bowel movements and } \\
\text { hair loss }\end{array}$ & $\begin{array}{l}\text { US } \\
\text { neck+ } \\
\text { RAIU+ } \\
\text { FNAC }\end{array}$ & $\begin{array}{l}\text { Total } \\
\text { thyroidectomy } \\
+ \text { Radioiodine } \\
\text { Ablation }\end{array}$ & $\begin{array}{l}\text { Currently well and under } \\
\text { active follow-up }\end{array}$ \\
\hline Lima et al. [12] & 2018 & 49/F & $\begin{array}{l}\text { Cervical mass, } \\
\text { unexplained weight } \\
\text { loss, anxiousness, } \\
\text { sweating, and } \\
\text { insomnia }\end{array}$ & $\begin{array}{l}\text { US } \\
\text { neck+ } \\
\text { RAIU+ } \\
\text { FNAC }\end{array}$ & $\begin{array}{l}\text { Total } \\
\text { thyroidectomy } \\
+ \text { Radioiodine } \\
\text { Ablation }\end{array}$ & Asymptomatic at follow-up \\
\hline
\end{tabular}

\section{TABLE 1: List of reported cases of follicular variant of papillary thyroid carcinoma arising within a hot nodule.}

RAIU: Radioactive iodine uptake; US neck: Ultrasound neck; FNAC: Fine needle aspiration cytology; PET/CT: Positron emission tomography/computed tomography; FVPTC: Follicular variant of papillary thyroid carcinoma.

Reported year $=$ the year case report published

The presence of a follicular variant of papillary carcinoma of thyroid associated with hyperfunctioning thyroid nodule is rare. It is clinically very important that the finding of a hot nodule may indicate thyroid malignancy. After total thyroidectomy due to the potential for metastatic spread, a radioactive iodine whole-body scan should be performed to detect for residual disease. Patients require lifelong thyroid hormone replacement therapy and measurement of serum TSH and serum thyroglobulin for follow-up. This case highlights the importance of careful evaluation of a thyroid nodule to determine whether it is malignant or not.

\section{Conclusions}

The presence of a hot nodule cannot always rule out thyroid cancer. Therefore, careful evaluation of hot nodule is necessary so that malignancy does not get overlooked.

\section{Additional Information \\ Disclosures}

Human subjects: Consent was obtained by all participants in this study. Conflicts of interest: In compliance with the ICMJE uniform disclosure form, all authors declare the following: Payment/services info: All authors have declared that no financial support was received from any organization for the submitted work. Financial relationships: All authors have declared that they have no financial relationships at present or within the previous three years with any organizations that might have an interest in the submitted work. Other relationships: All authors have declared that there are no other relationships or activities that could appear to have influenced the submitted work.

\section{References}

1. Haugen BR, Alexander EK, Bible KC, et al.: 2015 American Thyroid Association Management 
Guidelines for adult patients with thyroid nodules and differentiated thyroid cancer: the American Thyroid Association Guidelines Task Force on thyroid nodules and differentiated thyroid cancer. Thyroid. 2016, 26:1-133. 10.1089/thy.2015.0020

2. Mirfakhraee S, Mathews D, Peng L, Woodruff S, Zigman JM: A solitary hyperfunctioning thyroid nodule harboring thyroid carcinoma: review of the literature. Thyroid Res. 2013, 6:7.

10.1186/1756-6614-6-7

3. Popoveniuc G, Jonklaas J: Thyroid nodules. Med Clin North Am. 2012, 96:329-349.

10.1016/j.mcna.2012.02.002

4. Rees DO, Anthony VA, Jones K, Stephens JW: Follicular variant of papillary thyroid carcinoma: an unusual cause of thyrotoxicosis. BMJ Case Rep. 2015, 2015:bcr2014207091. 10.1136/bcr2014-207091

5. Pazaitou-Panayiotou K, Perros P, Boudina M, Siardos G, Drimonitis A, Patakiouta F, Vainas I: Mortality from thyroid cancer in patients with hyperthyroidism: the Theagenion Cancer Hospital experience. Eur J Endocrinol. 2008, 159:799-803. 10.1530/EJE-08-0468

6. Wharry LI, McCoy KL, Stang MT, et al.: Thyroid nodules $(\geqslant 4 \mathrm{~cm})$ : can ultrasound and cytology reliably exclude cancer?. World J Surg. 2014, 38:614-621. 10.1007/s00268-013-2261-9

7. Azevedo MF, Casulari LA: Hyperfunctioning thyroid cancer: a five-year follow-up . Arq Bras Endocrinol Metabol. 2010, 54:78-80. 10.1590/S0004-27302010000100013

8. Bommireddipalli S, Goel S, Gadiraju R, Paniz-MondolFi A, DePuey EG: Follicular variant of papillary thyroid carcinoma presenting as a toxic nodule by I-123 scintigraphy. Clin Nucl Med. 2010, 35:770-775. 10.1097/RLU.0b013e3181e4dc7f

9. Ruggeri RM, Campennì A, Giovinazzo S, et al.: Follicular variant of papillary thyroid carcinoma presenting as toxic nodule in an adolescent: coexistent polymorphism of the TSHR and Gs $\alpha$ genes. Thyroid. 2013, 23:239-242. 10.1089/thy.2012.0279

10. Gabalec F, Svilias I, Plasilova I, Hovorkova E, Ryska A, Horacek J: Follicular variant of papillary carcinoma presenting as a hyperfunctioning thyroid nodule. J Pediatr Hematol Oncol. 2014, 36:94-96. 10.1097/MPH.0000000000000036

11. Kuan YC, Tan FH: Thyroid papillary carcinoma in a 'hot' thyroid nodule. QJM. 2014, 107:475476. 10.1093/qjmed/hct204

12. Lima MJ, Soares V, Koch P, Silva A, Taveira-Gomes A: Autonomously hyperfunctioning cystic nodule harbouring thyroid carcinoma - case report and literature review. Int J Surg Case Rep. 2018, 42:287-289. 10.1016/j.ijscr.2018.01.002 